$$
\begin{array}{ccccccc}
\text { L } & \text { E } & \text { T } & \text { u } & \text { v } & \text { о } & \text { s } \\
\hline \text { ARCHEOlogija } & 47
\end{array}
$$



Lietuvos istorijos institutas

\begin{tabular}{llllllll}
$\mathrm{L}$ & $\mathrm{I}$ & $\mathrm{E}$ & $\mathrm{T}$ & $\mathrm{U}$ & $\mathrm{V}$ & $\mathrm{O}$ & $\mathrm{S}$ \\
\hline
\end{tabular}

ARCHEOlogija 47 


\section{Leidybą finansavo}

\section{LIETUVOS MOKSLO TARYBA}

PAGAL VALSTYBINĘ LITUANISTINIŲ TYRIMŲ IR SKLAIDOS 2016-2024 METŲ PROGRAMĄ

(Finansavimo sutarties numeris S-LIP-19-4)

\section{Redaktorių kolegija / Editorial board:}

Atsakingoji redaktorė / Editor-in-chief dr. Agnè Čivilytė (Lietuvos istorijos institutas, Vilnius / Lithuanian Institute of History, Vilnius)

Atsakingosios redaktorès pavaduotoja / Assistant Editor dr. Elena Pranckènaitè (Lietuvos istorijos institutas, Vilnius / Lithuanian Institute of History, Vilnius)

Dr. Laurynas Kurila (Lietuvos istorijos institutas, Vilnius / Lithuanian Institute of History, Vilnius)

Dr. Valdis Bērziņš (Latvijos universitetas, Latvijos istorijos institutas, Ryga / University of Latvia, Institute of Latvian History, Riga)

Habil. dr. Anna Bitner-Wróblewska (Valstybinis archeologijos muziejus Varšuvoje, Lenkija / State Archaeological Museum in Warsaw, Poland)

Dr. Christoph Jahn (Baltijos ir Skandinavijos archeologijos centras, Šlèzvigas, Vokietija / Center for Baltic and Scandinavian Archaeology, Schleswig, Germany)

Prof. dr. Rimantas Jankauskas (Vilniaus universitetas, Lietuva / Vilnius University, Lithuania)

Akad. prof. dr. Eugenijus Jovaiša (Lietuvos mokslu akademija, Vilnius / Lithuanian Academy of Sciences, Vilnius)

Habil. dr. Bartosz Kontny (Varšuvos universitetas, Archeologijos fakultetas, Lenkija / Faculty of Archaeology, University of Warsaw, Poland)

Prof. dr. Valter Lang (Tartu universitetas, Estija / University of Tartu, Estonia)

Doc. dr. Algimantas Merkevičius (Vilniaus universitetas, Lietuva / Vilnius University, Lithuania)

Habil. dr. Tomasz Nowakiewicz (Varšuvos universitetas, Archeologijos fakultetas, Lenkija / Faculty of Archaeology, University of Warsaw, Poland)
Habil. dr. Grzegorz Osipowicz (Mikalojaus Koperniko universitetas, Torunè, Lenkija / Nicolaus Copernicus University, Toruń, Poland)

Dr. Gytis Piličiauskas (Lietuvos istorijos institutas, Vilnius / Lithuanian Institute of History, Vilnius)

Dr. Eve Rannamäe (Tartu universtitetas, Estija / University of Tartu, Estonia)

Dr. Andra Simniškyte (Lietuvos istorijos institutas, Vilnius / Lithuanian Institute of History, Vilnius)

Dr. Roberts Spirgis (Latvijos universitetas, Latvijos istorijos institutas, Ryga / University of Latvia, Institute of Latvian History, Riga)

Dr. Eugenijus Svetikas (Lietuvos istorijos institutas, Vilnius / Lithuanian Institute of History, Vilnius)

Dr. Andris Šnē (Latvijos universitetas, Ryga / University of Latvia, Riga)

Doc. dr. Gintautas Zabiela (Klaipédos universitetas, Lietuva / Klaipéda University, Lithuania)

Prof. dr. Šarūnas Milišauskas (Niujorko valstijos Bafalo universitetas, JAV / New York State University at Buffalo, USA)

Prof. dr. Timothy Chevral (Niujorko valstijos Bafalo universitetas, JAV / New York State University at Buffalo, USA)

Prof. dr. Johan Ling (Gioteborgo universitetas, Švedija / University of Gothenburg, Sweden)

Sekretorè / Secretary Dovilè Urbonavičiūtė-Jankauskienė

Redakcijos adresas / Editorial Board address:

Lietuvos istorijos institutas, Archeologijos skyrius

Tilto g. 17, LT-01101 Vilnius

Tel. (+370) 5 2614436, fax (+370) 52611433

e-mail: lietuvosarcheologija@gmail.com; civilytea@gmail.com

\section{Žurnalas registruotas: EBSCO Publishing: Central and Eastern European Academic Source European Reference Index for the Humanities and Social Sciences (ERIH PLUS)}




\section{TURINYS / CONTENT}

Agnè Čivilytė

Ernestine S. Elster

James Patrick Mallory
PRATARME் 7

FOREWORD 11

\section{MARIJA GIMBUTIENE் KAIP ASMENYBE் / MARIJA GIMBUTAS AS PERSONALITY}

MARIJA GIMBUTAS, HER EXCAVATIONS, AND THE CONCEPT OF OLD EUROPE / MARIJA GIMBUTIENĖ, ARCHEOLOGINIAI KASINĖJIMAI IR SENOJI EUROPA .15

MARIJA GIMBUTAS IN THE CLASSROOM, FIELD AND OFFICE: A SHORT PERSONAL REMINISCENCE / MARIJA GIMBUTIENE KLASĖJE, KASINĖJIMUOSE IR KABINETE: TRUMPI ASMENINIAI PRISIMINIMAI .31

Kornelija Jankauskaitė MARIJA GIMBUTIENÉ: KELIAUTOJA IR TYRĖJA / MARIJA GIMBUTAS: TRAVELLER AND RESEARCHER .43

\section{STRAIPSNIAI / ARTICLES}

Šarūnas Milišauskas MARIJA GIMBUTAS (GIMBUTIENĖ): THE BALTIC GODDESS .55 MARIJA GIMBUTIENĖ: BALTŲ DEIVE். .88

Julia Mattes

ANTHROPOMORPHIC FIGURINES, GYNOCENTRISM AND GIMBUTAS' RECEPTION INSIDE ARCHAEOLOGY AND BEYOND .91

ANTROPOMORFINĖS FIGŪRĖLĖS, GINOCENTRIZMAS IR MARIJOS GIMBUTIENĖS IDĖJOS ARCHEOLOGIJOJE BEI UŽ JOS RIBŲ 123

MELLAART, GIMBUTAS, GODDESSES, AND ÇATALHÖYÜK: EARLY ASSUMPTIONS AND RECENT PERSPECTIVES ON THE ÇATALHÖYÜK FINDS 125

MELLAARTAS, GIMBUTIENĖ, DEIVĖS IR ČATAL HIUJUKAS: PIRMOSIOS PRIELAIDOS IR NAUJAUSIA RADINIŲ IŠ ČATAL HIUJUKO APŽVALGA 143 
Sharada Srinivasan

Rasa Banytè-Rowell

Florin Gogâltan

Gytis Piličiauskas Edvardas Simčenka Justina Kozakaitè Žydrūnè Miliauskienė Giedrè Piličiauskienè Harry Kenneth Robson

Janusz Czebreszuk Agnè Čivilytė

Paulius Gritènas

Artūras Dubonis
GODDESS WORSHIP AND THE DANCING FORM: EXPLORING RITUAL IN INDIAN PREHISTORY AND SOUTH INDIAN ANTIQUITY 145 DEIVĖS GARBINIMAS IR ŠOKIO JUDESIO FORMA: RITUALAI INDIJOS PRIEŠISTORĖJE IR PIETŲ INDIJOS ANTIKOJE 164

MARIJA GIMBUTAS’ DISSERTATION AND ITS VALUE:

BURIAL CUSTOMS IN THE ROMAN IRON AGE. 167 MARIJOS GIMBUTIENĖS DISERTACIJA IR JOS SVARBA: ROMĖNIŠKOJO LAIKOTARPO LAIDOSENA 185

TRANSYLVANIA AND THE OF INDO-EUROPEAN MIGRATION PROBLEM. THE ROMANIAN PARADIGM 187 TRANSILVANIJA IR INDOEUROPIEČIŲ MIGRACIJOS PROBLEMA. RUMUNIJOS PARADIGMA 207

DONKALNIO IR SPIGINO KAPINYNŲ AKMENS AMŽIAUS ŽMONIŲ KILMÉ IR MOBILUMAS STRONCIO IZOTOPŲ ANALIZĖS DUOMENIMIS. 209

THE ORIGINS AND MOBILITY PATTERNS OF STONE AGE HUMANS FROM THE DONKALNIS AND SPIGINAS BURIAL GROUNDS ACCORDING TO STRONTIUM ISOTOPE ANALYSIS. . .232

PROFESSOR MARIJA GIMBUTAS' ADVENTURE WITH PREHISTORIC AMBER AND THE RESULTS FOR US. 235 MARIJOS GIMBUTIENÉS PRIEŠISTORINIO GINTARO TYRINĖJIMAI IR JŲ REIKŠMĖ ŠIANDIEN 247

\section{KITAIP APIE ARCHEOLOGIJĄ /} ALTERNATIVE PERCEPTIONS OF ARCHAEOLOGY

FILOSOFIJA KAIP ARCHEOLOGIJA 249

\section{RECENZIJOS / REVIEWS}

RYTIS JONAITIS, IRMA KAPLŪNAITE்.

SENKAPIS VILNIUJE, BOKŠTO GATVËJE. XIII-XV A.

LAIDOSENOS LIETUVOJE BRUOŽAI. .253

AUTORIŲ DE்MESIUI 259

GUIDELINES FOR AUTHORS 263 


\title{
TRANSYLVANIA AND THE OF INDO-EUROPEAN MIGRATION PROBLEM. THE ROMANIAN PARADIGM
}

\author{
FLORIN GOGÂLTAN
}

Institutul de Arheologie și Istoria Artei Cluj-Napoca/Universitatea Babeș-Bolyai, Cluj Napoca, România; Str. Mihail Kogălniceanu, nr. 12-14, Cluj-Napoca 400084, România; e-mail: floringogaltan@gmail.com.

In this article, I discuss the manner in which the model proposed by Marija Gimbutas regarding the IndoEuropean migration in Europe was perceived by Romanian specialists. The article is also an extension of my efforts to understand the relations between prehistoric Transylvania and the North-Pontic steppe. Approached from this historiographic perspective, the subject illustrates a situation symptomatic of Romanian archaeology: the lack, with few exceptions, of serious debates on this controversial subject, the frequent repetition of unverified opinions, statements supported by invalid arguments, etc.

Keywords: Marja Gimbutas, Indo-Europeanization, North-Pontic steppe, Transylvania, Romania.

Šiame straipsnyje aptariama, kaip Rumunijos mokslininkai prième Marijos Gimbutienès pasiūlyta indoeuropiečių migracijos ị Europą modelį. Taip pat šiame darbe autorius siekia išaiškinti priešistorèje gyvavusius ryšius tarp Transilvanijos ir šiaurès Ponto stepių. Straipsnis parodo, jog iš istoriografinio konteksto akivaizdu, kad tema atskleidžia Rumunijos archeologijos mokslo padetį: rimtu diskusiju šia prieštaringa tema stoką (su keliomis išimtimis), dažną nepagrįstų nuomonių kartojima bei neteisingais argumentais paremtus teiginius.

Reikšminiai žodžiai: Marija Gimbutas (Gimbutienè), indoeuropeizacija, šiaurès Ponto stepè, Transilvanija, Rumunija.

On this occasion, I wish to present the way in which M. Gimbutas' theory about the Indo-Europeanization of Europe was received by Romanian scholars. I will also point out the starting moments of the debates on what was the impact of North-Pontic communities on the local environment. Approached from this historiographic perspective, the subject illustrates a situation symptomatic of Romanian archaeology: the lack, with few exceptions, of serious debates on this controversial subject, the frequent repetition of unverified opinions, statements supported by invalid arguments, etc. (Anghelinu 2003; Palincaș 2006; Dragoman, Oanță-Marghitu 2006; etc.). These circumstances led Professor Al. Vulpe to take a rough stance against those who thought that the Indo-Europeanization problem has already been solved (Vulpe 2008). The article is also an extension of my efforts to understand the relations between the prehistoric communities of Transylvania and the North-Pontic world (Gogaltan 2011; 2016; 2021).

It is known that the theoretical discourse has had little to no impact on Romanian archaeologists (Anghelinu 2007). As presented in the article, their arguments in regards to the Indo-European problem, if such thing ever existed, were based on the relationship between professor and disciple, or, plainly, on personal intuition. This approach was subject to some changes only after 1989. Naturally, a new generation of archaeologists developed, ready to bring a different style to their participation in the scientific process. Often starting as a rejection of the moral authority claimed by some established archaeologists in the old regime, the validity of their scientific opinions is also questioned. Personal relationships suffered as well; however, there were visible transformations, driven by a growing 
independence thanks to better access to bibliographic sources, thus breaking the monopoly of personal libraries. New academic models prevailed, while the scientific discussions turned to a more critical view, a natural reflection of the social turmoil that overwhelmed Romania at the end of the twentieth and beginning of the twenty-first century (Dragoman, Oanță-Marghitu 2013). However, this new reality had a limited impact over the Indo-European problem; therefore, the Gimbutas model remained an educational template, still unquestioned and unreviewed.

In 1888, G. Téglás was the first archaeologist to find analogies for a syenite mace-head uncovered at Cetea (western Transylvania) (Fig. 1) in the very place that is the Caucasus (Kuban) (Téglás 1888, 417). The first time when professional research was conducted on mounds from Romania was during the First World War. In 1917, C. Schuchhardt and P. Traeger probed two such monuments near Constanța, proving their burial function (Schuchhardt, Traeger 1919). Having published a stone stela found in a ravaged burial mound from Hamangia, V. Pârvan took the next step of establishing that there were analogies for the Transylvanian stelae from Baia de Criş and Gherla and he correctly pointed out that they belong to the Bronze Age. However, he believed that they come from Central, North and West-Europe, and that the Transylvanian ones were the easternmost (Pârvan 1925, 429).

The hypothesis that connections existed between the north of the Black Sea and their western neighbours was promoted by V. G. Childe already in the 1920's (Childe 1925; 1926). Childe talks more about Transylvania in his classic The Danube in Prehistory. A series of 'intrusive cultural groups' are to blame for the emergence of barrows bearing red ochre laden skeletons in crouched position. These mounds 'indubitably attest to relations between the Hungarian plain and South Russia across the Carpathians' (Childe 1929, 206). Other mounds from Transylvania, found in the valleys of the Olt and Mureş rivers, which contained crouched skeletons, could be tied to ochre graves found along the Tisza (Childe 1929, 208). Responding to this theory, the Decea Mureşului cemetery was put by I. Nestor in a separate group, which would have contained local (Bodrogkeresztúr) elements and south Russian influences ('südrussischen Affinitäten'). However, Nestor did not agree that actual steppe nomads had arrived in Transylvania (Nestor 1933, 73-76).

After I. Andrieşescu published in 1929 the zoomorphic stone sceptres from Sălcuța and Fedeleşeni (Andrieșescu 1929), the way was open for discussing this type of artifact. V. Dumitrescu gave rise to the hypothesis that these heads, which look a bit like hippos, would demonstrate Copper Age links between the Lower Danube and Egypt (Dumitrescu 1934, 190-200). Upon investigating the contents of the Dobrujan Casimcea grave, D. Popescu compared a zoomorphic stone sceptre with finds from the North Black Sea area ('Russie méridionale'). Among these, he drew connections with some artifacts of the same type from Transylvania: Decea Mureşului, 'Käsberg (Braşov)' and 'Vaia' (Popescu 1941, 91).

In the beginning of his career, professor K. Horedt gave much attention to a series of stone mace-heads from Cetea, Decea Mureşului, Feldioara, etc. (Horedt 1940), and a snake-like ax from 'Alba Iulia' with an animal head stylized next to the blade's edge (Horedt 1945), all from Transylvania. He also tied them with the north of the Black Sea (Fig. 2).

In 1941, I. Nestor and M. Petrescu-Dîmbovița saved the contents of several Bronze-Age graves discovered at Ploieşti-Triaj in southern Romania. In 1943, an untouched mound was dug up (Nestor 1944). Unfortunately, the results of this research were published only 45 years later (Comșa 1989). Nonetheless, the earlier finds, marked the 1950s 
debate on ochre mound burials in Muntenia and Moldova, according to their identification in the steppe and pre-steppe of the south USSR (PetrescuDîmbovița 1950). M. Petrescu-Dîmbovița was also the first to use in Romania the term Yamnaya burials ('înmormîntări de tip yamy') coined by V. A. Gorodtsov at the beginning of the 20th century (Kaiser 2019, 24) and then adopted by V. G. Childe ('yamno graves') (Childe 1942, 130-131).

The new archaeological finds after the Second World War prompted more researchers to take up Childe's newer or older views. The most renowned was and is M. Gimbutas (Gimbutas 1956; 1965; 1994; 1997). In the 1970s, M. Gimbutas developed the theory of the three main Kurgan migration waves (Gimbutas 1977; 1979). While there was general agreement for the first (4400-4300 BC) and the third wave (30002900 BC), researchers were divided when it came to the second migration wave, which supposedly lead to major cultural changes on the Middle and Lower Danube circa the mid-4th millennium BC (Gogâltan 2016, 419).

Just as I. Nestor before the Second World War, V. Dumitrescu had a more nuanced view (Dumitrescu et al. 1954, 540-544; Dumitrescu 1955; 1957, 8996; 1962; 1972). According to him, if the Casimcea grave belonged to the 'circle of the Black Sea steppe culture', the horse-head sceptres from Fedeleşeni and Sălcuța 'must be considered local mimicry of the type of sceptres found in Casimcea, made of another stone' (Dumitrescu et al. 1954, 542). This statement was later reconsidered. Their wide range from Oltenia to Caucasus was now due to 'tribal exchange' (Dumitrescu 1955, 929; 1957, 95). They were 'crafted also in the Black Sea steppe, but reached where they were found through trade between tribes' (Dumitrescu 1955, 929). The abstract sceptre from Văleni, Transylvania (Gogâltan 2011, 107, Abb. 5/2, with the old references) (Fig. 3) has been tied to the Caucasus 'through the tribes of the Black Sea steppe' (Dumitrescu et al. 1954, 544), and the zoomorphic

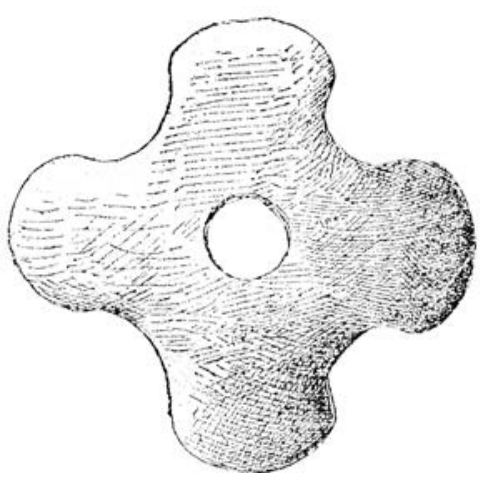

Fig. 1. The syenite mace-head uncovered at Cetea, Romania (after Teglas 1888).

1 pav. Kuoka iš sienito, aptikta Cetea, Rumunija (pagal Teglas 1888).

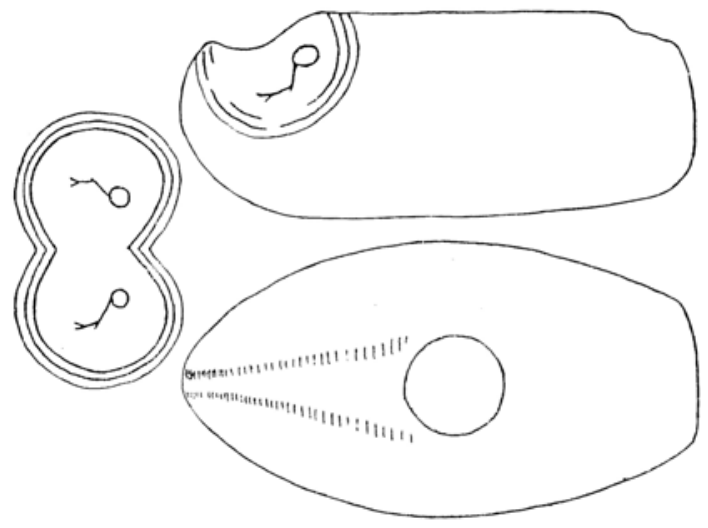

Fig. 2. Stone ax from 'Alba Iulia' (after Horedt 1945).

2 pav. Akmeninis kirvis iš „Alba Julija“ (pagal Horedt 1945).

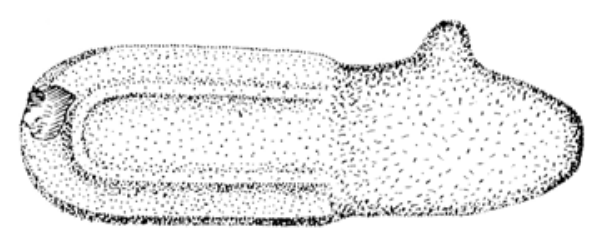

Fig. 3. The abstract stone scepter from Văleni, Romania (after Gogaltan 2011).

3 pav. Abstrakčios formos akmeninis skeptras, Valeni, Rumunija (pagal Gogaltan 2011). 
one from Suvodol had reached Macedonia through 'exchanges between tribes' (Dumitrescu 1962, 97).

Other interesting views were put forth by yet another founder of an archaeological thought school from the 1960s in Romania. D. Berciu thought that the Decea Mureşului cemetery was part of an independent Copper Age group or culture from Transylvania, with strong ties to the world north of the Black Sea (Berciu 1960a, 59-60). As to the diffusion of stone sceptres 'they were linked with the historical moment of the gradual migration of nomad shepherds [...]' (Berciu 1954, 546). In his opinion, there would have been five such waves from east and north-east, which lead to the formation of mixed cultures (Berciu 1960b, 73). Furthermore, 'on a social level, the entering of shepherd tribes, which were, in this respect, on a higher level of organization, sped up the integration of local tribes in the patriarchal order of things, and on the other side, it contributed to changing the language of these European regions towards Indo-European' (Berciu 1960b, 75). This view abruptly turned around when similar artefacts were found in Serbia and Bulgaria. These suggested instead an Aegean-Anatolian influence (Berciu 1962, 401, 407). From this point, Indo-Europeanization flowed in reverse: 'Their diffusion in the Terek basin, in the North Caucasus and towards the Caspian See and Lower Volga could possibly have begun from the South, through the Derbent mountainpass, likewise in the chronological framework of that general structural stage of the Indo-European languages' (Berciu 1962, 407).

In the 1950s, an ever greater number of burial mounds were excavated in eastern and southern Romania. Their inventory could be seen as the characteristics of a 'culture of red ochre graves' (Zirra 1960). Anthropological studies made on them seemed to bring further proof of links to the Black Sea steppe (Necrasov, Cristescu 1957). It was not long before this became the 'official' interpretation (Berciu 1960b, 72; Nestor 1960, 126). Also around that time, in a history of Transylvania, C. Daicoviciu surprisingly stated: 'Proto-Thracians. the newcomers, part of a long and important wave of migration, are, as is generally believed, Indo-European peoples [...]. Newer theories hold, however, that Indo-Europeans were on the territory of our fatherland since the beginning of the Palaeolithic Age' (Daicoviciu 1960, 19). Such a hypothesis had not yet been formulated by Romanian archaeologists, but it quickly found its followers among non-specialists.

P. Roman, the representative of a new generation of archaeologists, noticed differences in funeral rite and ritual. He correctly dated the ochre graves to a wider span of time from the Copper Age to the Early Bronze Age (Roman 1964). The contribution of A. D. Alexandrescu about menhir-statues refers directly to the situation in Transylvania. As the three artefacts from Baia de Criş were republished (Fig. 4), she concluded that they belong to an eastern type. They were not necessarily linked to the kurgans. Rather, they were a result of 'a second entry of eastern elements in Transylvania', which corresponded to the final stage of the Coțofeni culture (Alexandrescu 1963, 149). This view is still held to be true today, 55 years after it was first put forth (Rişcuța 2001; Gogâltan 2016, 430-434).

In 1970s and 1980s Romania, research on burial mounds received less financial support from the authorities. The effort that had to be put in conducting such excavations was likely considered to be not worth it due to insufficient results. Therefore, the discussion turned to historiography. Just as I. Nestor (Nestor 1970, 72), H. Daicoviciu would write that 'the penetration of shepherd tribes would mark the beginning of the process of the Indo-Europeanization of the peoples of these lands' (Daicoviciu 1971, 18). V. Dumitrescu would come back to discussing the horse head-shaped stone sceptres after reading an article by M. Gimbutas. He would revert to the hypothesis that 'the stone sceptres from Oltenia and Moldova need not be tied to the entering of steppe 

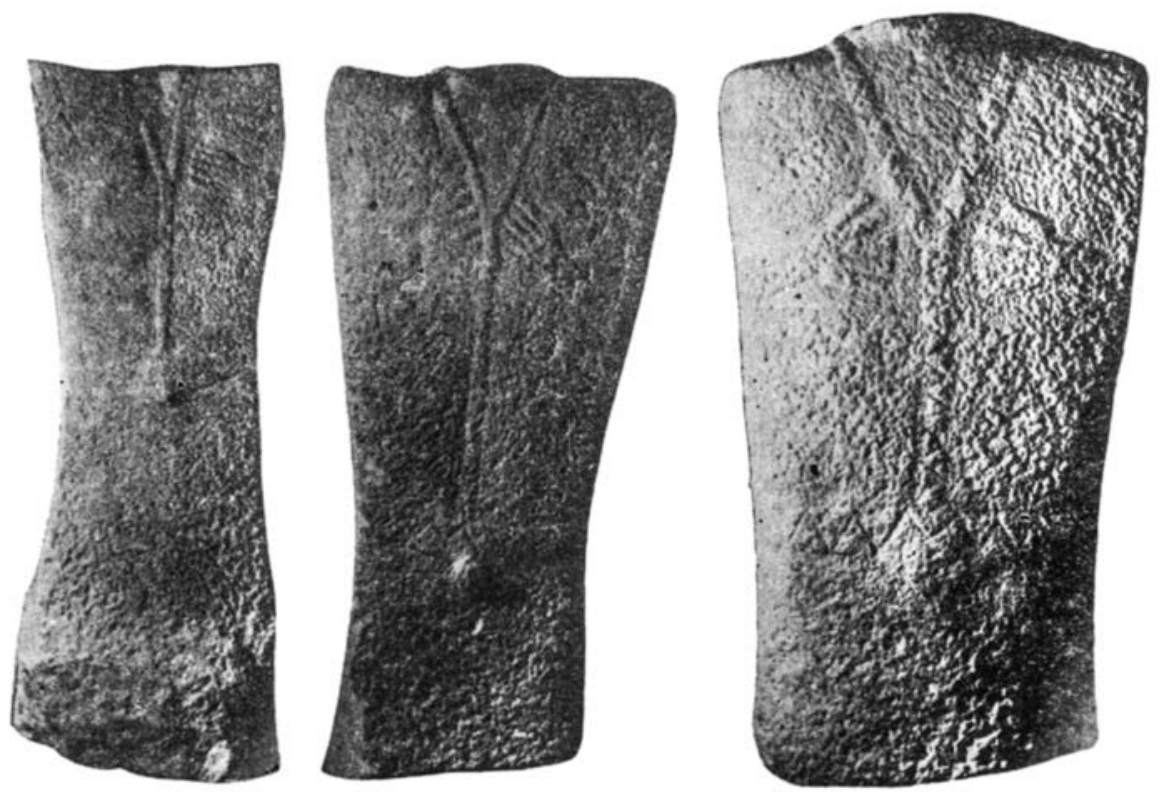

Fig. 4. The menhir-statues from Baia de Criş, Romania (after Alexandrescu 1963).

4 pav. Menhyro tipo skulptūros, Baja de Kriš, Rumunija (pagal Alexandrescu 1963).

tribes in this area. They are not local imitations, being made in places inhabited by tribes north of the Black Sea and got here through exchange' (Dumitrescu 1972, 48). On the other hand, M. Brudiu wrote that the few newer found abstract and animal-like stone sceptres prove relationships between the Cucutenian world and groups of people from north of the Black Sea (Brudiu 1975, 177; Brudiu, Coman 1979, 103). I also found I. Ferenczi's conclusion to be interesting. After probing the only certain Yamnaya barrow from Transylvania, which is located in Câmpia Turzii, he wrote that the communities from north of the Black Sea which got all the way inside the Carpathian Basin were not Indo-European. This was supposedly proven by the anthropological features of the individuals, and by the strong influences local people had on them (Ferenczi 1974, 133).

For this time, M. Dinu seems to have been the greatest partisan of M. Gimbutas' theories. He claimed unabashedly that the mounds from the steppe and forest steppe between the Volga and the middle course of the Danube, including the Balkan Peninsula, can be seen as part of IndoEuropeanization (Dinu 1974, 262). He further stated that: 'En admettant que les civilisations mixtes de transitions de type Cernavoda-Renie et HorodişteaFolteşti-Gorodsk-Ousatovo, utilisant de tombes planes avec on sans ocre, représentent la première synthèse historique réalisée par les premiers Indoeuropéens dans l'espace carpato-danubien, alors, le processus de l'indo-européanisation de la population locale ne peut plus être attribué aux tribus aux tombes tumulaires à ocre, qui comme on l'à déjà vu, sont postérieures aux civilisations susmentionnées' (Dinu 1974, 273).

In 1980, the articles from the second International Congress of Thracology were published. Definitely not by chance, this was another moment when the Indo-Europeanization theory was activated, as there was a desire to identify the origin of the Thracians. 
During his prestigious scientific career, E. Comşa also undertook serious work on the topic of the westward migration of the steppe peoples (Comșa 1976; 1978; 1980; 1989; 1998; etc.). He repeatedly insisted on connections between the local communities and the steppe people, which 'contributed to this long process, which ended through the IndoEuropeanization of the people from the CarpatoDanubian regions, and subsequently, the forming of the old Thracian communities' (Comșa 1978, 363). Furthermore, 'Dans ses territoires, les débuts du processus d'«indo-européanisation» se situent à la fin du IVe millénaire' (Comșa 1998, 29). During the same conference, $M$. Dinu restarted the debate on Indo-Europeanization, this time focusing on a series of discoveries, including from Transylvania, which were supposedly connected to a migration from Eastern Europe. It was about indications of horse taming and the emergence of the wagon. His conclusion was in line with the Gimbutas' model: 'Donc, si l'interprétation philologique est juste, ces découvertes constituent des indices de la présence des Indo-Européens dans l'espace carpato-danubien et balkanique bien avant la pénetration des tribus tumulaires' (Dinu 1980, 47).

A. Dodd-Oprițescu is another specialist who showed constant interest for the connecting elements between the North-Pontic steppe and Transylvania (Dodd-Oprițescu 1978). As she was well versed in the topic, she thought of the 'Decea Mureşului group' as a foreign entity in the late Tiszapolgár-Bodrogkeresztúr horizon (Dodd-Oprițescu 1980, 556). In a debate for and against migration, she proved to have a welcome non-partisan position about the stone sceptres: 'We are waiting for more things to be uncovered, and until then, we should stay away from theories which turn out to be extremist' (Dodd-Oprițescu, Mitrea 1980, 92). She took a similar stance regarding the corded ornaments (Dodd-Oprițescu 1981, 525). However, about the Cucuteni C pottery, she reminded them that 'only Cernavodă I communities are likely to be the first Indo-European groups to have entered the Western regions north of the Black Sea' (DoddOprițescu 1980, 556).

P. Roman also had a strong position about the Indo-Europeanization phenomenon of South-Eastern Europe. For him, the first groups in the northeastern and eastern regions, which moved west at the beginning of the 'Late Copper Age', had contributed to 'deepening the Indo-Europeanization process and to the shaping of the Thracian peoples' (Roman 1981, 22-23). In 1989, during the Congress of Thracology at Tulcea, P. Roman took part with a presentation about 'The Indo-Europeanization Phenomenon and the making of the Thracian Kind'. I will cite a paragraph from the introduction of this article. It should help us get the authour's view about who the Indo-Europeans were: 'Altogether, when explaining the spread of the Indo-Europeanization phenomenon, researchers failed to see that the moving groups of people put in motion also other, non-Indo-European ethnic groups. On the other hand, Indo-Europeanization of a given land could take long, and even be interrupted by non-Indo-Europeans coming back, or by the natives absorbing the Indo-European immigrant communities' (Roman 1989, 49-50). The next pages contain archaeological information from the 'second half of the 4th millennium and the 3rd millennium BC'. Unluckily, we do not find out anything else neither about these Indo-Europeans, nor about who the 'Non-Indo-Europeans' are.

Now, just as in the last 55 years, it is still a matter of hot debate whether items such as the abstract and animal-like sceptres or four-knobbed stone maces came from the east or from the west. However, because they lack archaeological contexts, the discussion stagnated. Since B. Govedarica and E. Kaiser published their synthesis article on abstract and zoomorphic stone sceptres (Govedarica, Kaiser 


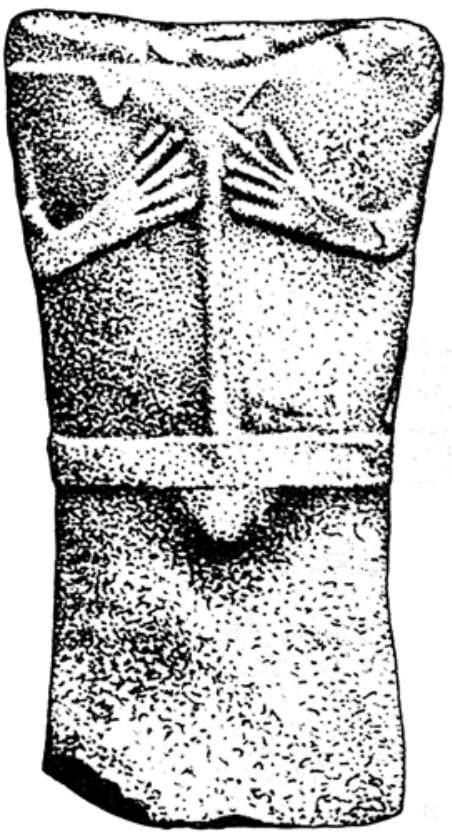

Fig. 5. The stone stelae from Baia de Criş, Romania (after Rişcuţa 2001). 5 pav. Akmeninès stelos, Baja de Kriš, Rumunija (pagal Rişcuța 2001).

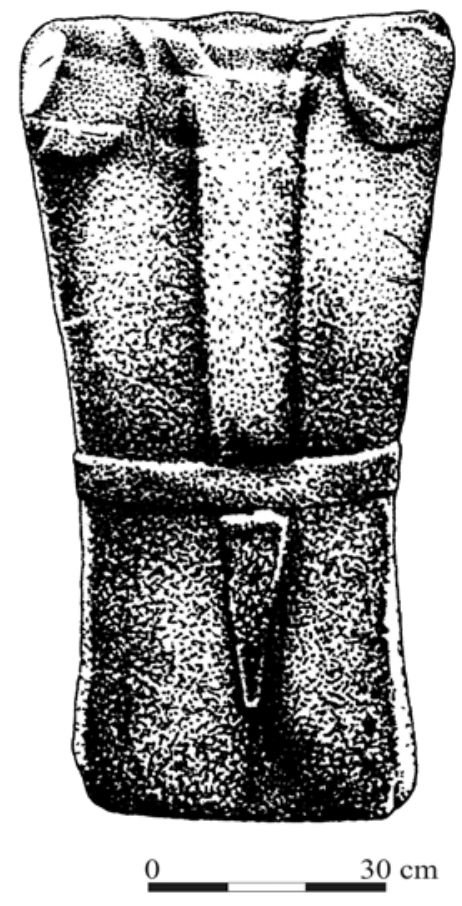

1996), and B. Govedarica on four-knobbed stone maces (Govedarica 2006), new finds (Burtănescu, Țurcanu 1997; Ciugudean 1998; Frînculeasa, Mirea 2007; Niculică 2008; Ilie 2012; Garvăn, Munteanu 2012; Garvăn 2018) and viewpoints (Harțuche 2005; Dergačev 2007, 56-90, 102-103, 112-119, 140-143, 210-212) were published. Opinions stay divided: some lean towards a Carpatho-Danube-Balkan origin (Burtănescu, Țurcanu 1997, 76, 82; Harțuche 2005, 82; Frînculeasa, Mirea 2007, 41-42), others still follow the migrationist theory of M. Gimbutas (Ciugudean 1998, 32; Dergacev 2000, 38, 42, 49-50; Măndescu et al. 2000, 21; Dergačev 2007, 465-468; Niculică 2008, 30-32).

In Transylvania, H. Ciugudean is also known for his investigation of a great number of burial mounds dated to the Early Bronze Age (Ciugudean 1991). Therefore, his topic of choice for his $\mathrm{PhD}$ does not come as a surprise (Ciugudean 1996). What really amazes me is that, given the times, his opinions did not match the expectations of his coordinator, who took an undeservedly critical stance (Roman 2000). Finds from the mounds proved that Yamnaya elements were there also in the middle of Transylvania. This could explain why inhumation was adopted by the native population. Aside this 'traditionalist' view, one can also see the 'emergence of barrow cemeteries as a result of a local development of a post-Neolithic society, which finds itself in the middle of a gradual process of transformation' (Ciugudean 1996, 132). As it is hard to specify the chronological relations between the incomers from the North-Pontic steppe and the natives, and because the Yamnaya distribution area does not overlap with the Livezile distribution area, it is hard to determine what role the foreign groups might have played in the making of the Western-Transylvanian barrow phenomenon. The new theoretical interpretations on the nature of the contacts between the world of the North-Pontic steppe and the east of Central 
Europe, including some new archaeological finds, have made Ciugudean see the role of the Yamnaya communities in Transylvania as 'disseminated Transylvanian goods towards the Lower Danube or to the Tisza Plain' (Ciugudean 2011, 30), nothing to do with Indo-Europeans.

N.-C. Rişcuța, by publishing the new finds from Baia de Criş (Fig. 5), has brought an important contribution to the study of stone stelae. He was probably influenced by $\mathrm{P}$. Roman (his $\mathrm{PhD}$ coordinator), when he stated that 'along with the monuments from Baia de Criş, these can be dated within the second arrival stage of Indo-European shepherds, which is archaeologically documented, and which corresponds to the third Kurgan wave, and to the Yamnaya culture' (Rişcuța 2001, 152). The argument is oversimplifying and fallacious: where they come from, the stone stelae are used by the Yamnaya communities. It is a well-known fact that the Yamnaya are Indo-European. Therefore, stone stelae are proof of Indo-Europeans coming to Transylvania.

In the level pertaining to the Decea Mureşului group, in the settlement at Seuşa-Gorgan (western Transylvania), a broken 'Cucuteni C' pot with seashell and snail shell temper was found (Fig. 6). It was 'attributed to the so-called Indo-Europeanization process' (Ciută, Marc 2010, 20). No further information was supplied.

In Moldova, G. Dumitroaia and F. Burtănescu are among the PhD students of P. Roman who dealt with the Early Bronze Age. Their PhD's spatially or chronologically overlapped to some degree, but not all of what they wrote was the same. G. Dumitroaia, even if he belonged to a generation still under the influence of the old historical discourse, stated that the people of the transition from the Copper to the Bronze Age had a 'so-called Indo-European origin' (Dumitroaia 2000, 161). The analysis of F. Burtănescu regarding the Early Bronze Age from Moldova is well grounded and remains the go-to book when it comes to relations between the local cultural phenomenon and the ones coming from north of the Black Sea and Central Europe. The population movements are seen correctly as carrying 'cultural messages, but, sometimes, possibly, also some ethnic elements' (Burtănescu 2002, 83), but the Indo-Europeans no longer have anything to do with this. One has to remember his territorial and cultural division of the Western Yamnaya region into areas of 'compact primary peopling' (including South-East Moldova, Bărăgan and Dobrouja), areas of 'come-and-go / migration' (along the Danube) and an area of 'compact secondary peopling', as it seems to have been the case of eastern Hungary (Burtănescu 2002, 260). I would add here Western Romania, and maybe Transylvania.

The Early and Middle Bronze Age on the Lower Danube was of interest to I. Vasiliu, who was writing his $\mathrm{PhD}$ under the supervision of I. Paul at the University of Alba Iulia. During that time, he published some 'ochre burials' (Vasiliu 1995a; 1995b; 1995c; 1995d). At the time, many agreed with the way he explained why they were here around Lower Danube: 'Indo-European communities had moved around the Lower Danube, and we only know about them from burial mounds' (Vasiliu 1995a, 73). The options that he proposed later got more complex: aside the traditional explanation of how this practice diffused through the many Yamnaya groups, it is also possible that they were adopted by the native people in the context of the economic and social changes that took place in the Early Bronze Age (Vasiliu 2004, 131).

For G. Simion (Simion 2003) or M. Brudiu (Brudiu 2003), at the beginning of the 2000s, there still was a migration of Indo-European peoples to the Lower Danube, following exactly the narrative proposed by M. Gimbutas. M. Irimia had tried to somewhat organize relatively and culturally (based on P. Roman's chronology) all the discoveries of the Early Bronze Age from Dobrouja, without any mention 
of the Indo-Europeans (Irimia 2003). Furthermore, M. -D. Liuşnea, by analyzing the riddle of the Early Bronze Age in South-Eastern Europe, reached the conclusion that 'The premises, the conditions, and the consequences of changes that took place at the end of the Copper Age are much more complex than one could think at first, but from this viewpoint, one has to reconsider the whole Indo-Europeanization process' (Liușnea 2007, 97).

R. Băjenaru, in his $\mathrm{PhD}$ published 10 years later, made a synthesis of information about the different types of burials from Muntenia, from simple flat inhumation pit graves to simple pit barrows. By analyzing them, he reached a conclusion which was in line with that of his mentor, A. Vulpe: 'Despite some finds identical to the North-Pontic ones, the presence of such burial practices in SE Europe does not have to be seen necessarily as a result of a huge migration of shepherd, war-like and Indo-European people, which left the steppe and crushed the flowering Copper Age Carpato-Danubian civilization' (Băjenaru 2014, 234).

Around this time, A. Frînculeasa was interested in studying the Yamnaya graves from Muntenia (Frînculeasa 2007). Trying to overcome the wellknown clichés, he wrote that the current state of the research is rather subjective and does not give us an objective picture of what was more often than not named ochre graves.

I. Motzoi-Chicideanu left us with the widest funerary archaeology synthesis about the Bronze Age in our area. Obviously, he could not avoid the topic of the so-called Indo-European problem. He was well known for his aversion to the Institute of Thracology and those who have promoted it (P. Roman). However, I do not think that this was the sole reason why he harshly criticized the opinions of those who looked for a thousand-year old national identity. He was right to say that people ignored the fact that 'the IndoEuropean problem is first and foremost a linguistic one, and that archaeology does not have the tools to

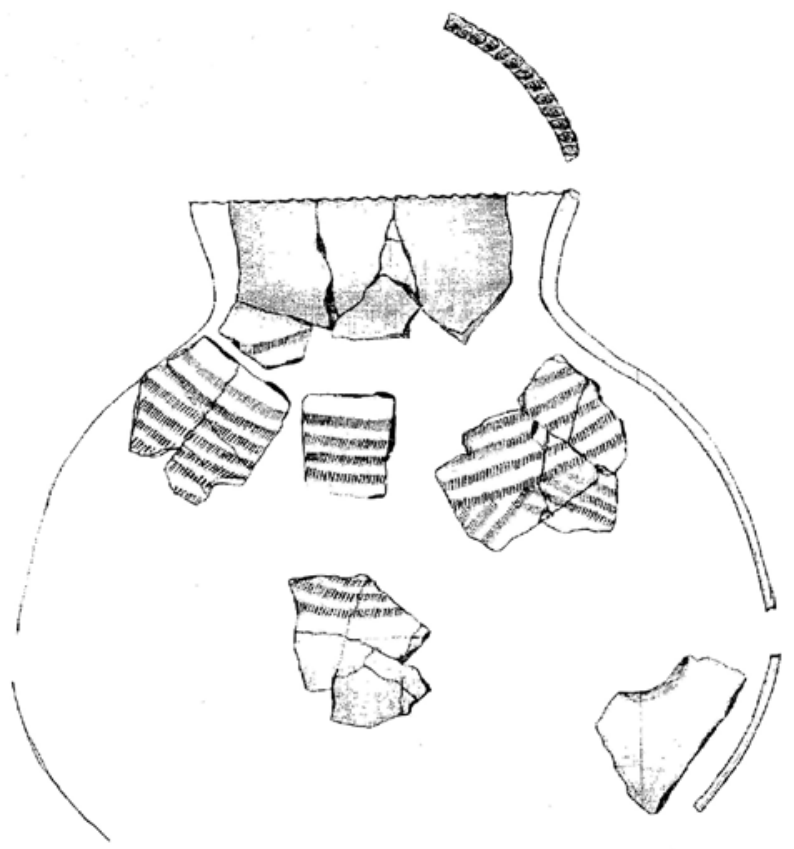

Fig. 6. A “Cucuteni C” pot from Seuşa-Gorgan, Romania (after Ciută, Marc 2010).

6 pav. Kukutenio C kultūrai priskiriama puodynè, Seuša-Gorgan, Rumunija (pagal Ciută, Marc 2010).

solve it' and 'the importance of the so called IndoEuropeanization was exaggerated, sometimes seen as starting as early as the Neolithic'. The archaeological cultures of Bronze Age Romania and bordering lands have been seen more and more as Thracian, although we do not have until today any attestations of language (Motzoi-Chicideanu 2011, 33).

I would like to finish this historiographic presentation with the thoughts of the late Professor A. Vulpe about the links with the North-Pontic steppe, and with this, about the problem of IndoEuropeanization. In his opinion the early shaft-hole axes supposedly did not come from the Caucasus, and were not passed around by eastern peoples (Vulpe 1974, 249). Besides, 'the alleged Indo-European people' did not bring about a break in the South-Eastern 
civilizations, and 'if we want to follow the IndoEuropeanization theory at this stage in history, we can accept it as an absorption by the newcomers of the former peoples and of a great part of their culture' (Vulpe 1979, 2266).

20 years later, the whole discussion resumed in the new treatise of Istoria românilor (The History of the Romanians). The importance raised by the 'Indo-European problem' and the fact that it is a 'word whose meaning was generalized more often than it should' (Vulpe 2001, 241), drove him to write about it in a separate subchapter of the same treatise. With the least possible amount of references, he debates matters of linguistics, and later touched upon the other hypotheses put forth by D. Antony and C. Renfrew about the spread of Indo-European languages. Regarding the theory of M. Gimbutas, A. Vulpe thought that it is 'a point of view which is little more than a working hypothesis' (Vulpe 2001, 246).

By analyzing migrations, in the context of the east $\rightarrow$ west model, he turned his attention to the movement of people, which took place between Central Asia and Europe in the pre- and protohistory, much like those that happened at the end of Antiquity up to the arrival of Genghis Khan's Mongols (Vulpe 2006, 30). The supposed migrations of shepherd people also belong to this model, where they put an end to Copper Age cultures such as the Cucuteni, Karanovo-Gumelnița, and so on. These migrations are also the alleged cause of the spread of primitive Indo-European languages. In his view, the use of the inductive method of interpretation on archaeological artefacts leads to dangerous historical generalizations. It would be better to follow the new trend in archaeology (New Archaeology), which developed the deductive method, which starts from generalizations (premises) to specific instances. Thus, the processualist method allegedly includes the changes in the environment with all their effects on economic, social and spiritual structures (Vulpe 2006,
37). Therefore, there can be causes other than migration to explain the end of the Copper Age 'cultures'. In this sense, he writes about changes in economy from a mainly agrarian one to a pastoral one, which is essentially influenced by the climate. He adds further factors that can bring about this change: the passing around of goods in very wide areas, brought on by new technological advances (such as the wagon and draught animals), and the quick adoption of new inventions (Vulpe 2006, 39-40).

In another article, which contained his thoughts on a debate about Indo-Europeans, A. Vulpe stated that as an archaeologist and historian, he cannot explain the diffusion of Indo-European languages from the Atlantic to Bangladesh or Sri Lanka. According to him, in order to do this, one has to identify the alleged Urheimat (Homeland) and then one has to prove that a fully developed 'culture' moved from one place to another. Besides, such an event cannot even be proven, since any moving community takes on several structural changes (economically, socially or ideologically), which affects the unity it had in the beginning. The fact that there are artefacts spread around a more or less large area can be explained in multiple ways and does not necessarily mean that migrating people are the cause. Obviously, this phenomenon also cannot be denied: 'In other words, the circulation of artefacts does not necessarily imply also the circulation of people over long distances, much less of ethnic groups, but can explain the migration of lexical items, which depend on the nature of the given artefacts' (Vulpe 2008, 25). Long story short, he points out the migrationist models of C. Renfrew, which, besides, seem to him unlikely to be true, and those of M. Gimbutas, which were accepted in Romania by specialists such as P. Roman and G. Simion. His conclusion is that 'I do not believe that I can join either position regarding the Indo-European languages. I do not think that a satisfying solution can be found in the current state of research' (Vulpe 2008, 27). 
In the preface of R. Băjenaru's $\mathrm{PhD}$, A. Vulpe raised a question which he admitted to have asked himself many times: 'what could have possibly driven these cattle herders of the steppe - these supposed Indo-Europeans - to leave the environment in which they subsisted, migrating towards the swampy forests of Central Europe or those of the Lower Danube?' (Vulpe 2014, 14). The answer should be searched for by making clear the climatic conditions of the Early Bronze Age.

The opinions of A. Vulpe, as well as some contributions made by E. Kaiser (Kaiser 2003), Y. Rassamakin (Rassamakin 2004), B. Govedarica (Govedarica 2004), R. Harrison, V. Heyd (Harrison, Heyd 2007), and many others, filtered through the perspective of current archaeological realities in Transylvania, encouraged me to decide to create a theoretical model which I deemed appropriate for understanding the relations between local prehistoric communities and the north-Pontic world.

The existence of clear contacts (collective or individual) in the second half of the 5th millennium BC contributed to the transfer or diffusion of technological innovations. Apart from metal objects (made from copper or gold), certain types of artefacts also circulated in a vast area during this time: specific stone maces, large flint blades, stone or bone sceptres with abstract or zoomorphic shapes, axes decorated on the sharp edge with schematic animal heads, and pottery with crushed shell temper. Even if we might have a vague idea, we cannot fully understand, based on tangible evidence, the full spectrum of the economic repercussions set in motion by these influences. Even less can be said about a possible renegotiation of the social structures in Transylvania during the late Tiszapolgár and Bodrogkeresztúr ceramic cultures (Gogâltan 2011, 102-104).
It is not possible to discuss collective contacts between Transylvania and the Pontic steppe in the middle of the fourth millennium bc, because the second Kurgan migration wave, as proposed by M. Gimbutas, cannot be proven. Only from the first half of the third millennium bc is there documented evidence of the presence of Yamnaya communities in the mid-Mureș Valley. Relevant archaeological discoveries are scarce, making it hard to establish the intensity of potential contacts with the local Coțofeni medium. Considering this, there is insufficient evidence to prove the steppe populations were responsible for the major changes that occurred in Transylvania at the beginning of the Early Bronze Age. Based on certain metal artefacts or distinct funerary practices, potential individual connections were often presumed. However, for the period towards the end of the first half of the third millennium bc, I consider certain stone or metal weapons and adornments, as well as the funerary mounds and the stone anthropomorphic stelae, to be in fact representations of social status for the elites involved in a trans-regional dialog (Gogâltan 2016, 438) (Fig. 7). The existence of Yamnaya funerary monuments in western Romania (Banat and Crișana) is a reality. The lowland area, part of the Great Hungarian Plain, along with eastern Hungary and the Serbian Banat can be included in the distribution area of the Yamnaya communities (Frînculeasa 2020b, Fig. 1; Diaconescu 2020, Fig. 1; Gogâltan 2021, Fig. 1).

Similar interpretations concerning the relationship between Pontic communities and the regions they influenced between the fifth and third millennia $\mathrm{BC}$ can be found in recent studies by the Romanian specialists interested in the movement of peoples and products (Frînculeasa et al. 2015; Preda 2015; Frînculeasa 2019; Preda-Bălănică et al. 2020). The current theoretical models concerned with mobility or the transfer of technological knowledge are in a similar position. 


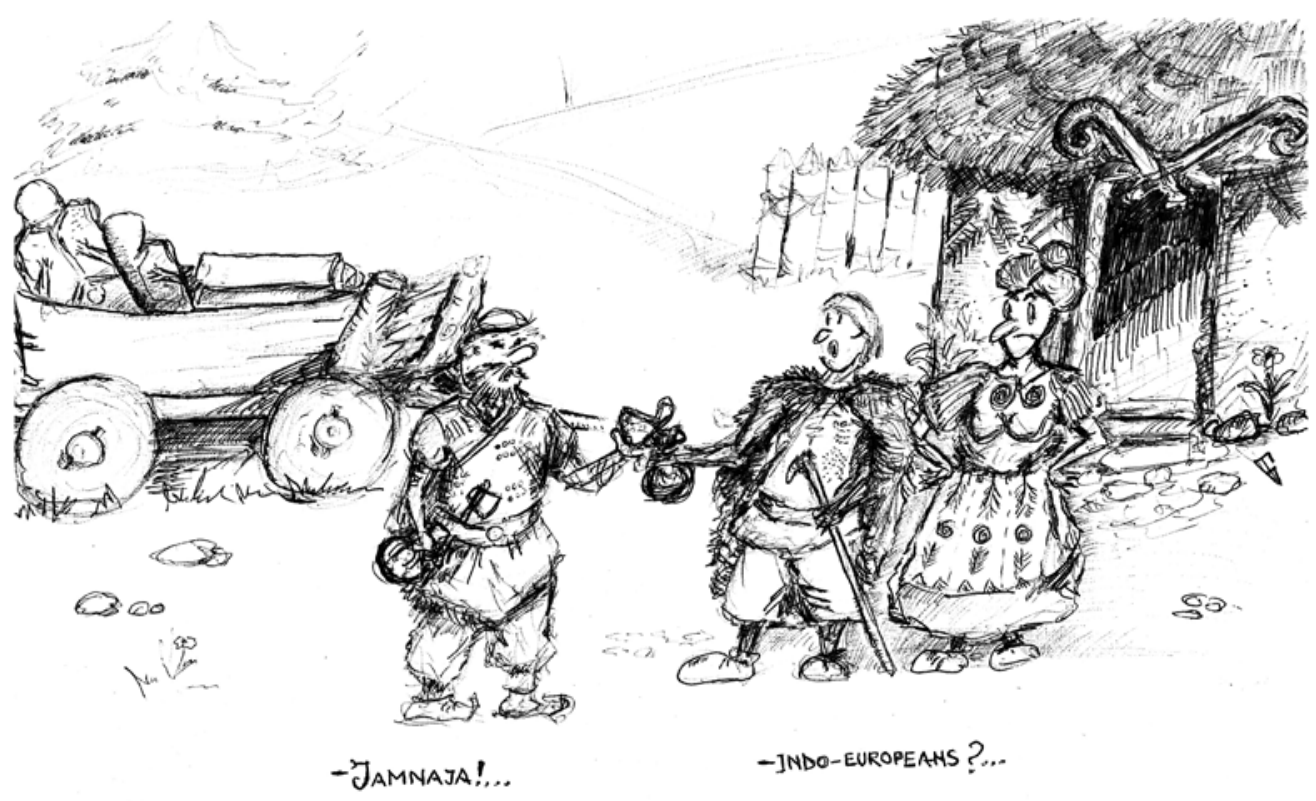

Fig. 7. Transilvania and the Indo-Europeanization phenomenon. Drawing by Gelu Florea.

7 pav. Transilvanija ir indoeuropeizacijos fenomenas. Gelu Florea pieš.

In the last years, the research of funerary mounds in Romania became increasingly connected to a wider spectrum of inter-disciplinary approaches, catching up with European trends. A few examples are eloquent in this regard. A coherent project focused on the mound phenomenon was developed by A. Frînculeasa and his team in southern Romania (Frînculeasa et al. 2017; 2019; Frînculeasa 2020a; etc.). Needless to say, the results are remarkable and capable of changing our way of interpreting such burial practices and their impact on the local environment. Efforts to get enough absolute dates, anthropological and metallographic analyzes, were also made by S. Ailincăi and his team while investigating the mounds in Rahman and Dobruja (Ailincăi et al. 2016). The research performed on the four tumuli in Silivașu de Jos (2006-2017), proved the appearance of a new burial rite and ritual (individuals lying supine, oriented westwards). This demonstrates the presence of Yamnaya communities in southwestern Transylvania (Diaconescu, Tincu 2016, 115;
Diaconescu 2020, 23), an opinion supported by other researchers as well (Preda-Bălănică et al. 2020, 96; Gogâltan 2021).

If this positive trend will be continued, there is hope to integrate the thousands of burial mounds in southern and eastern Romania into a vivid prehistory, with or without Indo-Europeans.

The so-called Cucuteni C ceramic style, also linked several years ago with the North-Pontic area, was analyzed in regards to its technological characteristics, targeting the chemical and mineralogical composition of the temper used. Interestingly enough, the conclusion suggested that the potters tended to use nonstandard materials (Mățău et al. 2015).

The strontium and oxygen isotopes analyzed on a skeleton from the barrow of Sárrétudvari suggested that some individuals from the Apuseni Mountains (western Transylvania) traveled to the north-western Hungarian plains (Gerling 2015, 59-61, 223). Although the first timid steps were taken in 
this direction (Gerling, Ciugudean 2013; Hervella et al. 2015), the current genetic data available for prehistoric Transylvania is far from sufficient in order to include this area in some of the European studies dedicated to the reconstruction of Bronze Age populations (Beck et al. 2020). From a genetic point of view, the contribution of the steppe populations in the development of the Indo-European languages is considered as an undisputed fact (Haak et al. 2015). Hopefully, further research projects will bring more light into this matter.

The linguistic debate regarding the IndoEuropean homeland has also been added to the archaeological interpretations (Anthony, Ringe 2015). However, the scientific conclusions are still very reserved, unable to overcome some restraints. Nonetheless, 'The evidence presented thus far supports the Gimbutas - Mallory interpretative line' (Alexianu 2016, 83).

Once again, I took this opportunity to present my opinions in regards the so-called Indo-European problem. Therefore, I would like to close this investigation into the history of research with the thoughts of the father of the Romanian modern school of archaeology A. Vulpe: 'I strongly believe that the beauty of Indo-European research, in all of its aspects, is precisely in this unending discussion and critical evaluation of the hypotheses which are put forth' (Vulpe 2008, 28).

\section{ACKNOWLEDGMENTS}

I am grateful to Agnè Čivilytè for the invitation to participate to this volume. I would also like to thank Alin Frînculeasa, Cristian I. Popa and Bianca Preda-Bâlânicâ for the bibliography and discussions.

\section{REFERENCES}

Ailincăi, S., Mihail, F., Constantinescu, M., Carozza, L., Micu, C., Burens, A., 2016. Découverte d'un tumulus de l'âge du Bronze à Rahman, sur la commune de Casimcea (dép de Tulcea). Studii şi Cercetări de Istorie Veche și Arheologie, 67, 1, 29-52.

Alexandrescu, A.D., 1963. În legătură cu statuilemenhir de la Baia de Criş. Studii şi Cercetări de Istorie Veche, 14, 1, 145-150.

Alexianu, A., 2016. In Search of the IndoEuropean Homeland: The Indo-Uralic Hypothesis. In: Zanoci, A., Kaiser, E., Kashuba, M., Izbitser, E., Băț, M., (eds.). Mensch, Kultur und Gesellschaft von der Kupferzeit bis zur frühen Eisezeit im Nördlichen Eurasien (Beiträge zu Ehren zum 60. Geburtstag von Eugen Sava). Man, culture, and society from the Copper Age until the Early Iron Age in Northern Eurasia (Contributions in honour of the 60th anniversary of Eugen Sava). Chișinău, 77-84.

Andrieşescu, I., 1929. Des survivances paléolithique dans le milieu néolithique de la Dacie. Academie Roumaine. Bulletin de la Section Historique, 15, 1-8.

Anghelinu, M., 2003. Evoluția gândirii teoretice în arheologia românească. Concepte şi modele aplicate in preistorie. Târgovişte: Cetatea de Scaun.

Anghelinu, M., 2007. Failed revolution: marxism and the romanian prehistoric archaeology between 1945 and 1989. Archaeologia Bulgarica, IX, 1-36.

Anthony, D.W., Ringe, D., 2015. The IndoEuropean Homeland from Linguistic and Archaeological Perspectives. Annual Review of Linguistics, 1, 1, 199-219.

Băjenaru, R., 2014. Sfârşitul bronzului timpuriu în regiunea dintre Carpați şi Dunăre. Cluj Napoca: Argonaut.

Beck, J., Ciugudean, H., Quinn, C.P., 2020. Bioarchaeology and Mountain Landscapes in Transylvania's Golden Quadrangle. Bioarchaeology International, 4, 2, 89-110. 
Berciu, D., 1954. Asupra problemei aşa-numitelor sceptre de piatră din R.P.R. Cu prilejul publicării unei descoperiri similare din Caucazul de nord (U.R.S.S.). Studii şi Cercetări de Istorie Veche, 5, 3-4, 539-548.

Berciu, D., 1960a. Perioada de înflorire a organizării gentilice matriarhale. Epoca nouă a pietrei (neoliticul). Neoliticul mijlociu (circa 35002800 î.e.n.). In: Istoria României, I, Bucureşti: Editura Academiei R.P.R., 44-60.

Berciu, D., 1960b. Prima mare diviziune socială a muncii. In: Istoria României, I, Bucureşti: Editura Academiei R.P.R., 72-82.

Berciu, D., 1962. A Zoomorphic «Sceptre» Discovered in the People's Republic of Bulgaria and Its Cultural and Chronological Position. Dacia N.S., VI, 397-409.

Brudiu, M., 1975. Despre două sceptre de piatră descoperite în sud-estul Moldovei. Studii şi Cercetări de Istorie Veche și Arheologie, 26, 2, 169-179.

Brudiu, M., 2003. Lumea de sub tumulii din sudul Moldovei. De la indo-europeni la turanicii târzii mărturii arheologice. Bucureşti: Printech.Brudiu, M., Coman, G., 1979. Un nou sceptru de piatră descoperit în sud-estul Moldovei. Studii şi Cercetări de Istorie Veche și Arheologie, 30, 1, 101-103.

Burtănescu, F., 2002. Epoca timpurie a bronzului între Carpați şi Prut cu unele contribuții la problemele premergătoare epocii bronzului în Moldova. București: Vavila Edinf SRL.

Burtănescu, F., Țurcanu, S., 1997. Un nou sceptru eneolitic descoperit în Moldova. Thraco-Dacica, XVIII, 75-95.

Childe, V.G., 1925. The Dawn of European Civilization. Londra: K. Paul, Trench, Trubner \& Co. Childe, V.G., 1926. The Aryans. A Study of IndoEuropean Origins. Londra: Dorset Press.

Childe, V.G., 1929. The Danube in Prehistory. Oxford: AMS Press.

Childe, V.G., 1942. Prehistory in the URSS. II. The Cooper Age in South Russia. Man, 42, 130-136.
Ciugudean, H., 1991. Zur frühen Bronzezeit in Siebenbürgen im Lichte der Ausgrabungen von Ampoița, jud. Alba. Praehistorische Zeitschrift, 66, 1, 79-118.

Ciugudean, H., 1996. Epoca timpurie a bronzului în centrul şi sud-vestul Transilvaniei. Bucureşti: Institutul Român de Tracologie.

Ciugudean, H., 1998. Noi descoperiri cu caracter 'stepic' în eneoliticul transilvănean. Apulum, XXXV, 31-36.

Ciugudean, H., 2011. Mounds and Mountains: Burial Rituals in Early Bronze Age Transylvania. In: Berecki, S., Németh, R., Rezi, B., (eds.). Bronze Age Rites and Rituals in the Carpathian Basin. Proceedings of the International Colloquium from Târgu Mureş 8-10 October 2010. Târgu Mureş: Mega, 21-57.

Ciută, M.-M., Marc, A.T., 2010. Un vas ceramic Cucuteni C, descoperit la Şeuşa-Gorgan (jud. Alba). Considerații preliminare. Studia Universitatis Cibiniensis. Series Historica, VII, 17-29.

Comşa, E., 1976. Considérations portant sur les tombes à ocre de la zone du Bas-Danube. Istraživanja, $5,33-58$.

Comşa, E., 1978. Unele probleme privind populațiile de stepă din nord-vestul Mării Negre, din perioada eneolitică până la începutul epocii bronzului. Studii şi Cercetări de Istorie Veche și Arheologie, 29, 3, 353-363.

Comşa, E., 1980. Contribution à la connaissance du processus d'«indo-européanisation» des régions carpato-danubiennes. In: Vulpe, R., (ed.). Actes du IIe Congrès Internaional de Thracologie (Bucarest, 4-10 septembre 1976). I. Histoire et archeology. Bucureşti: Editura Academiei Republicii Socialiste România, 29-33.

Comşa, E., 1989. Mormintele cu ocru din movila II-1943 de la Ploieşti-Triaj. Thraco-Dacica, 10, 1 81-188.

Comşa, E., 1998. Les tombes tumulaires à ocre sur le territoire de la Roumanie. In: Roman, P., (ed.). The Thracian World at the Crossroads of Civilisations. 
II. Proceedings of the Seventh International Congress of Thracology. Constanța-Mangalia-Tulcea 20-26 May 1996. Bucureşti: Vavila Edinf SRL, 15-36.

Daicoviciu, C., 1960. Din Istoria Transilvaniei, I. Bucureşti: Editura R.P.R.

Daicoviciu, H., 1971. Epoca străveche (comuna primitivă). In: Constantinescu, M., Daicoviciu, C., Pascu, S., (red.). Istoria României. Compediu. Bucureşti: Editura Didactică și Pedagogică, 12-33.

Dergacev, V., 2000. Două schițe în susținerea teoriei migraționiste. Considerații referitoare la problema interacțiunilor populației de stepă cu vechii agricultori din Europa de Est şi Sud-Est în perioada eneolitic-bronz timpuriu. Thraco-Dacica, XXI, 33-101.

Dergačev, V., 2007. O skipetrach, o lošadjach, o vojne. Etjudy v zaščitu migraciannog koncepcii M. Gimbutas. Sankt-Petersburg: Izd. 'Nestor-Istorija'.

Diaconescu, D., 2020. Step by Steppe: Yamnaya culture in Transylvania. Praehistorische Zeitschrift, 95, 1, 17-47.

Diaconescu, D., Tincu, S., 2016. Considerațiii arherologice privind necropola tumulară de la Silvaşu de Jos-„,Dealu Țapului” (oraş Hațeg, jud. Hunedoara). Analele Banatului, XXIV, 107-141.

Dinu, M., 1974. Le problème des tombes à ocre dans les régions orientales de la Roumanie. Preistoria Alpina, 10, 261-275.

Dinu, M., 1980. Le complexe Horodiştea-Folteşti et le problème de l'indo-européanisation de l'espace carpato-danubien. In: Vulpe, R., (ed.). Actes du IIe Congrès Internaional de Thracologie (Bucarest, 4-10 septembre 1976). I. Histoire et archeology. București: Editura Academiei Republicii Socialiste România, 35-48.

Dodd-Oprițescu, A., 1978. Les éléments «steppiques» dans l'énéolithique de Transylvanie. Dacia N.S., XXII, 87-97.

Dodd-Oprițescu, A., 1980. Considerații asupra ceramicii Cucuteni C. Studii şi Cercetări de Istorie Veche și Arheologie, 31, 4, 547-557.
Dodd-Oprițescu, A., 1981. Ceramica ornamentată cu şnurul din aria culturilor Cucuteni şi Cernavodă I. Studii şi Cercetări de Istorie Veche și Arheologie, $32,4,511-528$.

Dodd-Oprițescu, A., Mitrea, I., 1980. Sceptrul de piatră de la Mogoşeşti-Siret, județul Iaşi. Problema originii şi datării. Carpica, XV, 69-95.

Dragoman, R.A., Oanță-Marghitu, S., 2006. Archaeology in Communist and Postcommunist Romania. Dacia N.S., 50, 57-76.

Dragoman, R.A., Oanță-Marghitu, S., 2013. Arheologie și politică în România. Baia Mare: Eurotip.

Dumitrescu, V., 1934. Les figurines en pierre trouvées à Sălcuța et à Fedeleşeni (Roumanie) et le commerce entre l'Égypt et le Bas-Danube pendant la période énéolithique. Istros, I, 2, 187-200.

Dumitrescu, V., 1955. Cîteva precizări cu privire la sceptrele în formă de cal din R.P.R. şi din U.R.S.S. Studii şi Cercetări de Istorie Veche, 6, 3-4, 925-936.

Dumitrescu, V., 1957. Le dépôt d'objets de parure de Hăbăşeşti et le probléme des rapports entre les tribus de la civilisation de Cucuteni et les tribus des steppes pontiques. Dacia N.S., I, 73-96.

Dumitrescu, V., 1962. Un sceptru de piatră în formă de cal descoperit în Iugoslavia. Studii şi Cercetări de Istorie Veche, 13, 1, 95-99.

Dumitrescu, V., 1972. Din nou despre sceptrele de piatră în formă de cal. Pontica, 5, 45-52.

Dumitrescu, V., Dumitrescu, H., PetrescuDîmbovița, M., Gostar, N., 1954. Hăbăşeşti. Monografie arheologică. Bucureşti: Editura Academiei.

Dumitroaia, G., 2000. Comunități preistorice din nord-estul României. De la cultura Cucuteni până în bronzul mijlociu. Piatra Neamț: Editura Constantin Matasă.

Ferenczi, I., 1974. Új távlatok az erdélyi rézkor kutatásában. Az Aranyosgyéresen feltárt halomsír. Korunk, 33, 127-135.

Frînculeasa, A., 2007. Contribuții privind mormintele Jamnaja din Muntenia. Cercetările 
arheologice de la Ariceştii-Rahtivani - jud. Prahova. Tyragetia N.S., I (XVI), 1, 181-193.

Frînculeasa, A., 2019. The Children of the Steppe: descendance as a key to Yamnaya success. Studii de Preistorie, 16, 129-168.

Frînculeasa, A., 2020a. Endangered monuments: in rescue of the mutilated and anonymous burial mounds of the steppe. Revista de Arheologie, Antropologie şi Studii Interdisciplinare, 2, 41-79.

Frînculeasa, A., 2020b. Earthen burial mounds and the Coțofeni culture south of the Carpathians. Archaeological research in Ariceștii-Rahtivani Movila pe Răzoare. Ziridava. Studia Archaeologica, 34, 34-90.

Frînculeasa, A., Mirea, P., 2007. Asupra unei reprezentări zoomorfe descoperită în tell-ul Gumelnița de la Ciolăneştii din Deal, jud. Teleorman. In: Croitoru, C., (ed.). Perspective asupra istoriei locale în viziunea tinerilor cercetători. Miscellanea in memoriam Ştefan Stanciu. Galați: Istros, 37-46.

Frînculeasa, A., Preda, B., Heyd, V., 2015. PitGraves, Yamnaya and Kurgans along the Lower Danube: Disentangling IVth and IIIrd Millennium BC Burial Customs, Equipment and Chronology. Praehistorische Zeitschrift, 90, 45-113.

Frînculeasa A., Simalcsik A., Preda B., Garvăn D., 2017. Smeeni - Movila Mare. Monografia unui sit arheologic regăsit - Smeeni - Movila Mare. The monograph of a retrieved archaeological site. Târgoviște: Cetatea de Scaun.

Frînculeasa, A., Preda-Bălănică, B., Garvăn, D., Negrea, O., Soficaru, A., 2019. Towards a better understanding of the end of the fourth millennium bc in Northern Muntenia: the case of the burial mound in Ploiești - Gara de Vest. Ziridava. Studia Archaeologica, 33, 55-90.

Garvăn, D., 2018. Un sceptru zoomorf din piatră descoperit la Stăvărești (jud. Buzău). Mousaios, XXII, 2018, 133-140.

Garvăn, D., Munteanu, R., 2012. Un sceptru cruciform descoperit la Traian 'Dealul Fântânilor' (jud. Neamț). Buletinul Muzeului Județean teleorman. Seria Arheologie, 4, 167-173.

Gerling, C., 2015. Prehistoric Mobility and Diet in the West Eurasian Steppes 3500 to 300 BC. An Isotopic Approach. Berlin: De Gruyter.

Gerling, C., Ciugudean, H., 2013. Insights into the Transylvanian Early Bronze Age Using Strontium and Oxygen Isotope Analyses: A Pilot Study. In: Heyd, V., Kulcsár, G., Szeverényi, V., (eds.). Transitions to the Bronze Age. Interregional Interaction and Socio-Cultural Change in the Third Millennium BC Carpathian Basin and Neighbouring Regions. Budapest: Archaeolingue, 181-202.

Gimbutas, M., 1956. The Prehistory of Eastern Europe. Part I. Mesolithic, Neolithic and Cooper Age Cultures in Russia and the Baltic Area. Cambridge, Massachusetts: Peabody Museum.

Gimbutas, M., 1965. Bronze Age Cultures in Central and Eastern Europe. Paris, London: Walter de Gruyter.

Gimbutas, M., 1977. The First Wave of Eurasian Steppe Pastoralists into Copper Age Europe. Journal of Indo-European Studies, 5, 4, 277-338.

Gimbutas, M., 1979. The Three Waves of the Kurgan People into Old Europe, 4500-2500 B.C. Archives Suisses d'nthropologie genérale, 43, 2, 113-137.

Gimbutas, M., 1994. Das Ende Alteuropas. Der Einfall von Steppennomaden aus Südrußland und die Indogermanisierung Mitteleuropas. Budapesta: Archaeolingua.

Gimbutas, M., 1997. The Kurgan Culture and the Indo-Europeanization of Europe. Selected Articles from 1952 to 1993. Washington: Institute for the Study of Man.

Gogâltan, F., 2011. Die Beziehungen zwischen Siebenbürgen und dem Schwarzmeerraum. Die ersten Kontakte (cca. 4500-3500 v. Chr.). In: Sava, E., Govedarica, B., Hänsel, B., (eds.). Der Schwarzmeerraum vom Äneolithikum bis in die Früheisenzeit (5000-500 v. Chr.). Band 2: Globale Entwicklung versus Lokalgeschehen. Internationale 
Fachtagung von Humboldtianern für Humboldtianer im Humboldt-Kolleg in Chişinău, Moldavien (4-8 Oktober 2010). Berlin: Marie Leidorf GmbH, 101-124.

Gogâltan, F., 2016. Die Beziehungen zwischen Siebenbürgen und dem Schwarzmeerraum in der Kupfer- und am Anfang der Bronzezeit (ca. 3500ca. 2500 v. Chr.). In: V. Nikolov, V., Schier, W., (eds.). Der Schwarzmeerraum vom Neolithikum bis in die Früheisenzeit (6000-600 v. Chr.). Kulturelle Interferenzenin der Zirkumpontischen Zone und Kontakte mit ihren Nachbargebieten. Rahden/Westf: Marie Leidorf GmbH, 417-447.

Gogâltan, F., 2021. Transylvania. Within or outside of the Yamnaya world. In: Heyd, V., Kulcsár, G., Preda-Bălănică, B., (eds.). Yamnaya Interactions. Proceedings of the International Workshop held in Helsinki, 25-26 April 2019. The Yamnaya Impact on Prehistoric Europe, Vol. 2. Budapest: Archaeolingua, 243-270.

Govedarica, B., 2004. Zepterträger - Herrscher der Steppen. Die frühen Ockergräber des älteren Äneolithikums im karpatenbalkanischen Gebiet und im Steppenraum Südost- und Osteuropas. Mainz: Philipp von Zabern.

Govedarica, B., 2006. Die kreuzförmigen Steinkeulen in der frühen Kupferzeit Südost- und Osteuropas. In: Tasić, N., Grozdanov, C., (eds.). Homage to Milutin Garašanin. Belgrad: Serbian Academy of Sciences and Arts Macedonian Academy of Sciences and Arts, 415-431.

Govedarica, B., Kaiser, E., 1996. Die äneolitische abstrakten und zoomorphen Steinzepter Südost- und Osteuropas. Eurasia Antiqua, 2, 59-103.

Haak, W., Lazaridis, I., Patterson, N., Rohland, N., Mallick, S., Llamas, B., Brandt, G., Nordenfelt, S., Harney, E., Stewardson, K., Fu, Q., Mittnik, A., Bánffy, E., Economou, C., Francken, M., Friederich, S., Garrido Pena, R., Hallgren, F., Khartanovich, V., Khokhlov, A., Kunst, M., Kuznetsov, P., Meller, H., Mochalov, O., Moiseyev, V., Nicklisch, N., Pichler, S.,
Risch, R., Rojo Guerra, M., Roth, C., SzécsényiNagy, A., Wahl, J., Meyer, M., Krause, J., Brown, D., Anthony, D., Cooper, A., Werner Alt, K., Reich, D., 2015. Massive Migration from the Steppe was a Source for Indo-European Languages in Europe. Nature, 522, 207-211.

Harrison, R., Heyd, V., 2007. The Transformation of Europe in the Third Millenium BC: the Example of 'Le Petit-Chasseur I+III' (Sion, Valais, Switzerland). Praehistorische Zeitschrift, 82, 2, 129-214.

Harțuche, N., 2005. Sceptrele de piatră zoomorfe. Interpretare şi cronologie. Pontica, XXXVIIXXXVIII, 71-97.

Hervella, M., Rotea, M., Izagirre, N., Constantinescu, M., Alonso, S., Mihai, I., Lazăr, C., Ridiche, F., Soficaru, A.D., Netea, M., de-la-Rua, C., 2015. Ancient DNA from South-East Europe Reveals Different Events during Early and Middle Neolithic Influencing the European Genetic Heritage. PLoS ONE 10(6), 1-20.

Horedt, K., 1940. Südosteuropäische Keulenköpfe. Mitteinlungen der Anthropologischen Gesellschaft in Wien, 70, 283-301.

Horedt, K., 1945. Steinaxt mit tierkopfförmiger Spitze aus Siebenbürgen. Dacia, IX-X, 539-540.

Ilie, A., 2012. Un sceptre anthropomorphe de la collection d'archéologie du Complexe Nationale et Musée «La Cour Princière» de Târgovişte. Dacia, N.S., LVI, 33-46.

Irimia, M., 2003. Zur frühen Bronzezeit in der Dobrodscha. In: Kacsó, C., (Hrsg.). Bronzezeitliche Kulturerscheinungen im karpatischen Raum. Die Beziehungen zu den benachbarten Gebieten. Ehrensymposium für Alexandru Vulpe zum 70. Geburstag. Baia Mare 10.13. Oktober 2001. Baia Mare: Editura Casei Corpului Didactic, 249-265.

Kaiser, E., 2003. Studien zur Katakombengrabkultur zwischen Dnepr und Prut. Mainz: Philipp von Zabern.

Kaiser, E., 2019. Das dritte Jahrtausend im osteuropäischen Steppenraum. Kulturhistorische 
Studien zu prähistorischer Subsistenzwirtschaft und Interaktion mit benachbarten Räumen. Berlin: Edition Topoi.

Liuşnea, M.-D., 2007. Observații privind perioada bronzului timpuriu în sud-estul Europei. Peuce N.S., V, 77-106.

Măndescu, D., Cioflan, T., Maschio, R., 2000. Noi aspecte ale eneoliticului târziu în zona Argeşului. Argessis, IX, 19-24.

Mățău, F., Nica., V, Matricalău, A.-L., Stancu, A. 2015. Technological Characteristics of the Cucuteni C Pottery from Poduri-Dealul Ghindaru. Studia Antiqua et Archaeologica, 21, 2, 123-145.

Motzoi-Chicideanu, I., 2011. Obiceiuri funerare în epoca bronzului la Dunărea Mijlocie și Inferioară. București: Editura Academiei Române.

Necrasov, O., Cristescu, M., 1957. Contribuție la studiul antropologic al scheletelor din complexul mormintelor cu ocru de la Brăilița. Studii şi Cercetări de Istorie Veche, VIII, 1-4, 75-88.

Nestor, J., 1933. Der Stand der Vorgeschichtsforschung in Rumänien. Bericht der Römisch-Germanischen Kommission, 22, 11-181.

Nestor, I., 1944. Raport asupra cercetărilor şi săpăturilor de salvare făcute la Ploieşti-Triaj şi Brazi între 21 octombrie și 7 noembrie 1942. Raport asupra activității științifice a Muzeului Național de Antichități în anii 1942 și 1943, 29-31.

Nestor, I. 1960. Începuturile societății gentilice patriarhale şi ale destrămării orânduirii comunei primitive. Epoca bronzului. In: Istoria României, I, Bucureşti: Editura Academiei R.P.R., 90-113, 114-132.

Nestor, I., 1970. Les grandes problèmes de l'héritage de l'epoque des metaux. In: Sources archéologique de la civilisation européenne. Actes du Colloque international organisé par le Secrétariat général de l'AIESEE, sous le haut patronage et avec le concours financier de l'UNESCO. Mamaïa (Roumanie), 1-8 septembre 1968. București: Editura Academiei, 69-75.
Niculică, B., 2008. Noi date despre sceptrele cruciforme eneolitice descoperite pe teritoriul Moldovei. Arheologia Moldovei, XXXI, 23-42.

Palincaş, N., 2006. On Power, Organisation and Paradigm in Romanian Archaeology before and after 1989. Dacia N.S., 50, 7-56.

Pârvan, V., 1925. La «statue-menhir» de Hamangia. Dacia, II, 422-429.

Preda, B., 2015. Considerations regarding barrow burials and metal depositions during the Early Bronze Age in the Carpathian-Danube area. Hiperboreea Journal, 2, 5-51.

Preda-Bălănică, B., Frînculeasa, A., Heyd, V., 2020. The Yamnaya Impact North of the Lower Danube: A Tale of Newcomers and Locals. Bulletin de la Société préhistorique française, 117, 1, 85101.

Petrescu-Dîmbovița, M., 1950. Date noi asupra înmormântărilor cu ocru roşu în Moldova. Studii şi Cercetări de Istorie Veche, I, 2, 110-125.

Popescu, D., 1941. La tombe à ocre de Casimcea. Dacia, VII-VIII, 85-91.

Rassamakin, J. 2004. Die nordpontische Steppe in der Kupferzeit. Gräber aus der Mitte des 5. Jts. Bis Ende des 4. Jts. v. Chr. Mainz: Philipp von Zabern.

Rişcuța, N.C., 2001. O nouă descoperire arheologică la Baia de Criş (jud. Hunedoara). ThracoDacica, XXII, 139-171.

Roman, P., 1964. Despre unele aspecte ale perioadei de trecere de la epoca neolitică la epoca bronzului în regiunile exteracarpatice ale R.P.R. Revista Muzeelor, I, 4, 323-334.

Roman, P., 1981. Forme de manifestare culturală din eneoliticul tîrziu şi perioada de tranziție spre epoca bronzului. Studii şi Cercetări de Istorie Veche și Arheologie, 32, 1, 21-42.

Roman, P., 1989. Fenomenul indoeuropenizării şi constituirea neamului tracic la Dunărea inferioară în lumina cercetărilor arheologice. Symposia Thracologica, 7, 49-55. 
Roman, P., 2000. Review. Eneoliticul final în Transilvania şi Banat: cultura Coțofeni, de Horia Ciugudean. Thraco-Dacica, XXI, 309-312.

Schuchhardt, C., Traeger, P., 1919. Aufgrabung zweier Tumuli bei Constanza. Praehistorische Zeitschrift, 10, 150-155.

Simion, G., 2003. Migrația popoarelor indoeuropene la Dunărea de Jos. In: Simion, G., (ed.). Culturi antice în zona gurilor Dunării. Volumul I. Preistorie şi protoistorie. Cluj-Napoca: Nereamia Napocae, 13-50.

Téglás, G., 1888. Kőbuzogányokról az erdélyi medencze területén. Archaeologiai Értesitö, VIII, 417-421.

Vasiliu, I., 1995a. Cercetări arheologice în Delta Dunării. Mormintele cu ocru de la Chilia Veche. Peuce, XI, 49-88.

Vasiliu, I., 1995b. Mormintele cu ocru de la Luncavița, Movila Mocuța. Peuce, XI, 89-115.

Vasiliu, I., 1995c. Noi informații privind epoca bronzului în nordul Dobrogei. Movilele funerare de la Luncavița, punctul Drumul Vacilor. Peuce, XI, 117-140.

Vasiliu, I., 1995d. Date noi privind înmormântările cu ocru din Dobrogea. Movilele funerare de la Mihai Bravu. Peuce, XI, 141-175.
Vasiliu, I., 2004. Date noi privind epoca bronzului în nordul Dobrogei. Mormintele cu ocru de la Enisala-La Băltiță. Ialomița, IV, 123-136.

Vulpe, A., 1974. Probleme actuale privind metalurgia aramei şi a bronzului în epoca bronzului în România. Revista de Istorie, 27, 2, 243-255.

Vulpe, A., 1979. Puncte de vedere privind istoria Daciei preromane. Revista de Istorie, 32, 12, 2261-2284.

Vulpe, A., 2001. Problema indo-europeană. In: Petrescu-Dîmbovița, M., Vulpe, A., (Coord.). Istoria românilor. Vol. I. Moştenirea timpurilor îndepărtate. București: Editura Academiei Române, 241-247.

Vulpe, A., 2006. Migrații. O temă arheologică şi istorică. Modelul est $\rightarrow$ vest. Memoriile Secției de Științe Istorice și Arheologice, 31, 29-40.

Vulpe, A., 2008. Reflecții în urma unei dezbateri despre Indo-Europeni. In: Ailincăi, S., Micu, C., Mihail, F., (eds.). Omagiu lui Gavrilă Simion la a 80-a aniversare. Constanța: Editura Dobrogea, 23-28.

Vulpe, A., 2014. Prefață. In: Băjenaru, R. Sfârşitul bronzului timpuriu în regiunea dintre Carpați şi Dunăre. Cluj Napoca: Argonaut, 11-14.

Zirra, V., 1960. Kul'tura pogrebenij s ochroj v Zakarpatskich obalstjach RNR. Materialy $i$ issledovanija po archeologii Jugo-Zapada SSSR $i$ RNR, 97-127. 


\title{
TRANSYLVANIA AND THE OF INDO-EUROPEAN MIGRATION PROBLEM. THE ROMANIAN PARADIGM
}

\author{
Florin Gogâltan
}

\section{Summary}

The hypothesis that connections existed between the people north of the Black Sea and their western neighbours was promoted by V. G. Childe already in the 1920s. A series of intrusive cultural groups are to blame for the emergence of barrows containing red ochre laden skeletons in a crouched position. These mounds indubitably attest to relations between the Hungarian plain and South Russia across the Carpathians'. Other mounds from Transylvania, found in the valleys of Olt and Mureş rivers, which contained crouched skeletons, could be tied to the ochre graves found along the Tisza.

New archaeological finds after the Second World War prompted more researchers to take up Childe's newer or older views. The most renowned was and is M. Gimbutas. In the 1970s, M. Gimbutas developed the theory of three main Kurgan migration waves. While there was general agreement for the first (4400-4300 BC) and the third waves (3000-2900 вC), researchers were divided when it came to the second, which supposedly led to major cultural changes in the Middle and Lower Danube circa the mid-4th millennium BC.

The existence of clear contacts (collective or individual) in the second half of the 5th millennium $\mathrm{BC}$ contributed to the transfer or diffusion of technological innovations. Apart from metal objects (made from copper or gold), certain types of artefacts also circulated in a vast area during this time: specific stone maces, large flint blades, stone or bone sceptres with abstract or zoomorphic shapes, axes decorated on the sharp edge with schematic animal heads, and pottery with crushed shell temper. Even if we might have a vague idea, we cannot fully understand, based on the tangible evidence, the full spectrum of the economic repercussions set in motion by these influences.

It is not possible to discuss collective contacts between Transylvania and the Pontic steppe in the mid-4th millennium $\mathrm{BC}$, because the second Kurgan migration wave, as proposed by M. Gimbutas, cannot be proven. Only from the first half of the third millennium $\mathrm{BC}$ is there documented evidence of the presence of Yamnaya communities in the mid-Mureș Valley. Relevant archaeological discoveries are scarce, making it hard to establish the intensity of potential contacts with the local Coțofeni medium. Considering this, there is insufficient evidence to prove the steppe populations were responsible for the major changes that occurred in Transylvania at the beginning of the Early Bronze Age. Based on certain metal artefacts or distinct funerary practices, potential individual connections were often presumed. However, for the period towards the end of the first half of the third millennium BC, I consider certain stone or metal weapons and adornments, as well as the funerary mounds and the stone anthropomorphic stelae, to be in fact representations of social status for the elites involved in a trans-regional dialogue. The existence of Yamnaya funerary monuments in western Romania (Banat and Crișana) is a reality. The lowland area, part of the Great Hungarian Plain, along with eastern Hungary and the Serbian Banat can be included in the distribution area of the Yamnaya communities. 


\title{
TRANSILVANIJA IR INDOEUROPIEČIŲ MIGRACIJOS PROBLEMA. RUMUNIJOS PARADIGMA
}

\author{
Florin Gogâltan
}

\section{Santrauka}

Hipotezę apie ryšių tarp šiaurinių Juodosios jūros regionų bendruomenių ir vakarinių jų kaimynų palaikymą iškèlè V. G. Childas dar praejjusio amžiaus 2-ajame dešimtmetyje. Dèl kultūrinių grupių judrumo ir jų sąveikos susidarè savitas pilkapių kompleksas, kuriuose palaikai buvo laidojami suriesti ir padengti ochra. Šie pilkapiai „neabejotinai liudija Vengrijos lygumos ir pietų Rusijos ryšius per Karpatus“. Kiti Transilvanijos pilkapiai, rasti Olto ir $\mathrm{Mu}$ rešo upių slèniuose, kuriuose taip pat laidoti suriesti, galejo būti susiję su ochros kapais, rastais palei Tisą. Nauji archeologiniai radiniai po Antrojo pasaulinio karo paskatino daugiau tyrinètojų, tarp jų ir Mariją Gimbutienę, perimti naujesnius ar senesnius V. G. Childo požiūrius. Ji sukūrè trijų pagrindinių kurganų migracijos bangų teoriją. Tyrèjai sutarè dèl pirmosios (4400-4300 m. pr. Kr.) ir trečiosios bangos (3000-2900 m. pr. Kr.), bet nuomonès išsiskyrè dèl antrosios migracijos bangos, kuri tariamai lèmé didelius kultūrinius pokyčius Vidurio ir Žemutinio Dunojaus regione, maždaug IV tūkstantmečio pr. Kr. viduryje. Aiškių kontaktų (kolektyvinių ar individualių) egzistavimas antroje $\mathrm{V}$ tūkstantmečio pr. Kr. pusejje prisidejjo prie technologinių naujovių perdavimo ar sklaidos. Be metalinių objektų (pagamintų iš vario ar aukso), didžiuliame areale tuo metu cirkuliavo ir tam tikros rūšies dirbiniai: savitos akmeninès kuokos, didelès titnago skeltès, abstrakčių ar zoomorfinių formų akmeniniai ar kauliniai skeptrai, kirviai, puošti schemizuotų gyvūnų galvų atvaizdais ir keramika su smulkintų kriauklių priemaišomis. Net jei turètume miglotą idejją, remdamiesi apčiuopiamais įrodymais, negalime iki galo suprasti viso šių ịtakų sukeltų ekonominių pasekmių spektro. Neįmanoma diskutuoti apie kolektyvinius Transilvanijos kontaktus su Ponto stepių bendruomenèmis IV tūkstantmečio pr. Kr. viduryje, nes antroji kurganų migracijos banga, kurią pasiūlè M. Gimbutienè, neįrodyta. Tik nuo pirmos III tūkstantmečio prieš Kr. pusès yra duomenų, leidžiančių manyti, kad Murešo slènio viduryje įsikūrẻ Jamnajos bendruomenès. Vis dèlto sunku nustatyti galimų kontaktų su vietine Coțofeni kultūra intensyvumą. Atsižvelgiant i tai, nèra pakankamai ịrodymų, patvirtinančių, kad stepių populiacijos lèmé pagrindinius pokyčius, ịvykusius Transilvanijoje ankstyvojo bronzos amžiaus pradžioje. Remiantis tam tikrais metaliniais dirbiniais ar skirtingais laidojimo papročiais, dažnai buvo daroma prielaida, esą tarp šių bendruomenių galimi individualūs ryšiai. Tačiau pirmos III tūkstantmečio pr. Kr. pusès pabaiga datuojamus akmeninius ar metalinius ginklus bei papuošalus, taip pat pilkapius ir akmenines antropomorfines stelas galima interpretuoti kaip socialinio statuso reprezentacijas. Tai buvo bendruomenių elitas, dalyvavęs tarpregioniniame dialoge. Nèra abejonių, jog Jamnajos laidojimo paminklų yra vakarų Rumunijoje (Banate ir Krišanoje). Žemumų plotas, Didžiosios Vengrijos lygumos dalis, su rytų Vengrija ir Serbijos Banatu gali būti ịtrauktas i Jamnajos bendruomenių paplitimo zoną.

Vertè Agné Čivilyte

Gauta: 20211103 Priimta: 20211202 